\title{
The influences of speech rate, utterance length and sentence complexity of disfluency in preschool children who stutter and children who do not stutter
}

\author{
Yesul Kim • Hyunsub Sim* \\ Department of Communication Disorders, Ewha Womans University, Seoul, Korea
}

\begin{abstract}
According to Demand and Capacity Model (DCM), external and internal environments influence the disfluency of children who stutter (CWS). This study investigated the effects of simultaneous changes in motoric and linguistic demands on CWS and children who do not stutter (CWNS). Participants were 4-6 years old CWS and CWNS. A sentence imitation task with changes in speech rate, utterance length, and sentence complexity was used to examine their effects on children's disfluency. When the utterance length changed, CWS showed more disfluency regardless of utterance length and as the speech rate changed, CWS showed more disfluency at fast speech rate than CWNS. When the utterance length and speech rate changed, at fast speech rate, CWS showed more disfluency in both utterances than CWNS. When sentence complexity changed, CWS showed more disfluency than CWNS in complex sentences. Changes in linguistic elements such as speech rate, utterance length, and sentence complexity affect disfluency in CWS, especially when they were exposed to faster, longer, and more complex sentences. This indicates that CWS are vulnerable to fast and complex speech motor control and language processing ability than CWNS. Thus, this study suggests that parents and therapists consider both the speech rate and the utterance length when talking with CWS.
\end{abstract}

Keywords: stuttering, demand and capacity model, language ability, preschool children

\section{1. 서론}

학령전기 아동은 주위의 언어적 환경에 영향을 받는데, 특히 부모의 의사소통 스타일로부터 많은 영향을 받는다고 알려져 있다. 다수의 선행연구에서 아동의 말-언어환경이 말더듬 아동 에게 스트레스로 작용될 수 있다고 주장한다(e.g., Gottwald, 2010;
Starkweather,et al., 1990). 예를 들면, 질문에 대해 빠르게 반응해 야 하는 시간적 압박(time pressure), 복잡한 문장을 구성해야만 하는 상황적 요구나 정서적으로 불안한 상태에서 말을 해야 하 는 상황 등이 아동에게는 언어적 부담이 될 수 있다는 의미이 다. 요구용량 모델(demand and capacity model, Curlee, 2000; Starkweather \& Gottwald, 2000)에서도 학령전기 아동의 비유창

*simhs@ewha.ac.kr, Corresponding author

Received 31 January 2021; Revised 15 March 2021; Accepted 17 March 2021

(C) Copyright 2021 Korean Society of Speech Sciences. This is an Open-Access article distributed under the terms of the Creative Commons Attribution NonCommercial License (http://creativecommons.org/licenses/by-nc/4.0) which permits unrestricted non-commercial use, distribution, and reproduction in any medium, provided the original work is properly cited. 
성이 환경적 요구와 아동의 용량 사이의 불균형으로 인해 발생 한다고 본다. 이 모델의 기본 전제는 말더듬 아동의 인지적 용 량(복잡한 개념을 전달할 수 있는 능력), 언어적 용량(긴 문장이 나 복잡한 문장을 산출할 수 있는 능력), 운동적 용량(부드럽고 빨리 말을 할 수 있는 능력), 정서적 용량(정서적 스트레스가 있 는 상황에서 말을 할 수 있는 능력)이 아직 충분히 발달하지 않 았기 때문에, 자기 스스로(self-imposed) 또는 환경으로부터 과 도한 요구가 부가될 경우, 유창한 말이 산출되지 못하고 비유창 성이 발생 된다는 것이다(Adams, 1990). 즉, 외적 환경에 의해 부과되는 요구가 아동의 운동적, 언어적, 정서적 용량을 초과하 게 되었을 때 발화가 비유창하게 되며, 이러한 상황이 지속적으 로 발생하게 된다면 말더듬으로 발전될 수 있다고 본다 (Bernstein Ratner, 1997).

Kelly \& Conture (1992)에 의하면 학령전기 아동의 말더듬은 주 양육자의 언어학적 및 준언어학적 행동같은 환경적 요인과 연관성이 있기 때문에, 학령전기 말더듬 아동을 대상으로 간접 치료를 하기 위해서는 우선 아동과 부모 사이의 상호작용 평가 가 이루어져야 한다. 특히 아동-부모 상호작용 평가에서 부모의 말속도는 중요한 평가항목 중 하나이다. 그리고 간접 치료에서 는 아동의 비유창성을 감소시키기 위해 부모에게 느린 말속도 로 대화할 것을 제안한다(Ainsworth \& Fraser, 1998). Lee et al.(2003) 연구에서도 대화 상대자의 말속도가 아동의 말속도 보 다 느릴 경우 아동의 비유창성은 감소한다고 주장한다. 이러한 연구 결과는 부모의 말속도 감소는 아동이 발화를 계획하고 산 출하는데 충분한 시간을 제공함으로써 유창성 증진에 이바지 할 수 있다는 것을 시사한다(Conture, 1990).

일반적으로 말더듬은 언어장애가 아닌 말장애(speech disorders) 로 인식되어 오고 있지만, 말더듬과 언어발달의 관련성 여부는 중요한 연구주제로 계속 다루어졌다(e.g., Yaruss, 1999; Yaruss et al., 1999). Howell \& Au-Yeng(2007)은 말더듬이 말 산출의 단 계적인 측면에서 볼 때 언어적 계획(linguistic plan)과 말운동의 실행(the execution of speech movement) 사이에서 나타나는 상호 작용의 문제로 인해 발생한다고 주장한다. 이를테면 발화길이 와 통사적 복잡성에 관한 언어계획이 적절한 타이밍에 말운동 시스템에 전달되지 않았을 때 아동의 유창성에 부정적 영향을 미치는 것으로 알려져 있다(Zackheim \& Conture, 2003). 이런 이 유로 말더듬 아동들은 자신의 평균 발화길이(mean utterance length) 보다 긴 발화에서 더 많은 비유창성을 보인다고 한다 (Gaines et al., 1991).

또한 Bosshardt(2006)은 동시과제실험(dual task experiments) 을 통해 인지처리 부담(cognitive processing load)을 추가로 부과 했을 때 비유창성이 발생할 수 있다고 주장했다. 즉, 언어적 처 리와 주의집중이 요구되는 인지적 처리 과제를 동시에 제시하 면, 말을 더듬는 사람의 조음 - 음운 시스템은 일반인들보다 취 약하기 때문에 더 많은 간섭을 받게 된다고 한다. 하지만 말을 더듬는 사람의 경우, 동시과제의 인지처리 부담이 증가함에 따 라 항상 그에 상응하여 비유창성이 증가하는 것은 아니라고 한 다. 대신에 그들은 말산출을 위해 투자해야 할 인지처리 작업의
양을 감소시킨다고 한다. 즉 발화의 길이를 줄이거나 문장의 내 용을 단순하게 한다는 것이다. 이러한 이유로 말을 더듬는 사람 은 일반인보다 문장을 생성하고(generation), 생성된 문장을 구 어로 산출하는데 더 많은 처리 능력이 필요하다는 것이다 (Bosshardt, 2006).

이러한 맥락에서 보았을 때 말더듬 아동의 말속도와 발화길 이 및 통사적 복잡성에 따른 비유창성의 변화에 관한 연구는 부 모의 말속도 감소, 발화길이의 감소 및 문장구조의 단순화가 말 더듬 아동의 비유창성 감소에 중요한 임상적 시사점을 준다 (Sawyer, 2008). Zebrowski et al.(1996)은 말더듬 아동의 부모에 게 말속도를 조절하라는 권고와 함께, 발화의 수뿐만 아니라 발 화의 특성에 대한 대화지침도 병행해야 한다고 주장했다. 여러 연구에 의하면 말속도, 발화길이 및 통사적 복잡성 요인이 동시 에 아동의 유창성에 영향을 미친다고 하나 이러한 요인들을 체 계적이고 통합적으로 살펴본 연구는 드물다.

따라서 본 연구는 말더듬 아동과 일반아동의 말속도, 발화길 이 및 통사적 복잡성을 동시에 체계적으로 변화시켰을 때, 아동 의 비유창성이 어떻게 변화하는가를 분석하였다. 주로 아동의 자발화를 사용한 국내 선행연구와 달리 본 연구에서는 문장 따 라말하기(sentence repetition) 과제를 활용하였다. 문장 따라말 하기 과제는 아동이 문장을 듣고, 들은 문장을 그대로 반복하여 말하는 과정을 포함하기 때문에 언어이해와 산출과정 모두가 포함되어 있으며, 음운론적, 통사론적 그리고 의미론적인 수준 과 관련이 있는 과제이다(Marinis \& Armon-Lotem, 2015). 또한 문장 따라말하기 과제는 자발화에서 통제하기 힘든 외적 요인 들을 통제할 수 있으며(Silverman \& Ratner, 1997), 단시간에 언 어학적 구조를 끌어낼 수 있는 효율성(Hale-Haniff \& Siegel, 1981)을 가지고 있다. 나아가 제시 말속도, 발화길이 및 통사적 복잡성의 정도를 조절하여 아동의 음운부호화 능력과 작업기 억 능력에 체계적으로 부담을 줄 수 있다(Bonvillian et al., 1979). 본 연구는 이러한 문장 따라말하기 과제를 사용하여 말속도, 발 화길이 및 통사적 복잡성을 동시에 체계적으로 변화시켰을 때 말더듬 아동집단과 일반아동 집단 간의 비유창성 빈도에 유의 한 차이가 있는지를 분석하고 아동 개개인의 비유창성 특성을 살펴보았다. 또한, 이를 통해 말더듬 아동의 말 - 언어능력을 파 악하고, 부모에게 제공되는 말더듬 예방 및 치료에 관련된 임상 적 조언에 대한 실증적 기초자료를 제공하는 데 목적을 두었다.

\section{2. 연구 방법}

\section{1. 연구대상}

본 연구의 검사 대상자는 수도권을 비롯한 중부지역에 거주 하는 만 4-6세의 일반아동 9명과 말더듬 아동 9명, 총 18 명으로 구성하여 검사를 진행하였다.

일반아동은 (1) 표준화된 수용 - 표현 어휘력 검사(Receptieve \& Expressive Vocabulary Test; REVT; Kim et al., 2009) 결과에서 수용어휘와 표현어휘 모두 정상범위에 해당하며, (2) 표준화된 유창성 검사인 파라다이스 유창성 검사 ㅍ(Paradise-Fluency Test 
ㅍ, P-FAㅍ Sim et al., 2011) 결과에서 말더듬 중증도가 “약함” 에 해당하고, (3) 한국어 구문의미이해력 검사(Korean Sentence Comprehension Test, KOSECT; Pae et al., 2004) 결과 정상범위에 해당하는 아동으로서, (4) 보호자로부터 청각적 혹은 신경학적 문제 그리고 정서 - 행동에 이상이 없는 것으로 확인된 아동으 로 선별하였다. 말더듬 아동들은 (1) 표준화된 언어검사인 $\mathrm{REVT}$ 검사결과에서 수용어휘와 표현어휘 모두 정상범위에 해 당하며, (2) 표준화된 유창성 검사인 P-FAI 검사결과에서 말더 듬 중증도가 “중간에서 심함”에 해당하고, (3) 표준화된 한국어 구문의미이해력 검사결과 정상범위에 해당하는 아동으로서, (4) 보호자로부터 청각적 혹은 신경학적 문제, 정서 - 행동에 이 상이 없는 것으로 확인된 아동으로 선별하였다.

검사를 실시한 후 두 집단의 정규성 분포를 알아본 결과, Shaprio-Wilk 검정에서 생활연령이 $p<.05$ 로 나타나므로 SPSS (Statistical Package for Social Science)의 Man-Whitney 검정을 실 시하였다. 그 결과, 두 집단은 수용어휘점수 $(Z=-1.245, p=.222)$, 표현어휘점수 $(Z=-1.508, p=.132)$, 구문의미이해점수 $(Z=-.752$, $p=489$ )에서 유의한 차이를 보이지 않았다. 하지만 생활연령에 서는 유의한 차이가 있는 것으로 나타났다 $(Z=-2.302, p<.05)$. 집단 간 생활연령, 수용어휘와 표현어휘, 구문 · 의미이해의 차 이에 대한 Man-Whitney 비모수 검정 결과는 표 1에 나타나 있다.

표 1. 대상자 정보

Table 1. Participants' characteristics

\begin{tabular}{c|c|c|c|c}
\hline & $\begin{array}{c}\text { CWNS } \\
(\mathrm{n}=9)\end{array}$ & $\begin{array}{c}\text { CWS } \\
(\mathrm{n}=9)\end{array}$ & Z-value & $p$-value \\
\hline Age (months) & $\begin{array}{c}66.78 \\
(6.28)\end{array}$ & $\begin{array}{c}59.89 \\
(5.78)\end{array}$ & -2.302 & $.021^{*}$ \\
\hline Expressive & $\begin{array}{c}68.11 \\
(7.34)\end{array}$ & $\begin{array}{c}63.56 \\
(7.81)\end{array}$ & -1.508 & .132 \\
\hline language (score) & $\begin{array}{c}61.33 \\
(6.38)\end{array}$ & $\begin{array}{c}57.11 \\
(3.62)\end{array}$ & -1.245 & .222 \\
\hline Receptive & 32.67 & $\begin{array}{c}25.89 \\
(12.02)\end{array}$ & -.752 & .489 \\
\hline language (score) & $(14.73)$ & \multicolumn{1}{|c|}{ comprehension (score) } &
\end{tabular}

CWNS, children who do not stutter; CWS, children who stutter.

\section{2. 연구 절차 및 과제}

\subsection{1. 연구절차}

이 실험은 만 4-6세 아동 대상자의 가정이나 유치원을 방문 하여 조용한 공간에서 진행했다. 본 검사 전, 과제의 난이도를 파악하고 조정하기 위해 5 세 0 개월의 일반아동을 대상으로 예 비 실험을 진행하였다. 그리고 본 실험은 대상자를 선정하기 위 한 선별 검사와 연구과제로 구성이 되어 있다. 검사는 취학 전 아동의 정신적 그리고 신체적 피로감을 고려하여 총 2회로 나 누어 진행하였다. 첫 회기에서는 아동과 친밀감과 신뢰감을 형 성하기 위해 놀이시간을 가진 후 선별 검사(REVT, 구문의미이 해검사, P-FA프를 진행하였다.

그 후 선별 검사에서 실시한 유창성 검사 P-FA프의 하위 검 사 유형인 말하기 그림에서 아동의 발화 자료를 말더듬 유형에
따라 분석하고 음성 프로그램 Praat software version 60.40을 이 용하여 아동의 발화 지속 시간을 측정하여 아동 개개인의 평균 말속도를 구했다. 말속도는 발화 지속 시간(2초 이상의 쉼과 머 뭇거림을 제외한 지속 시간)을 내용 전달 음절수로 나눈 것으로 서 초당 음절수(Syllables Per Millisecond, ms/s)로 계산을 하였 다. 과제의 말속도는 전체의 평균 말속도로 녹음했을 때 개인차 로 인해 발생할 수 있는 비유창성을 줄이기 위해 개개인의 평균 말속도를 기준으로 하였다. 그리고 평균 말속도를 $30 \%$ 가감하 여 따라말하기 문장을 녹음하였다.

또한, 녹음된 문장의 자연스러움을 유지하기 위하여 말속도 를 조절할 때 문장 내 조음을 늘리지 않고 어절 간의 쉼을 조절 하였다(Goldman-Eisler, 1968). 발화길이와 통사적 복잡성을 조 절한 문장을 녹음할 때는 말속도의 변화 없이 평균 말속도로 통 일하였다.

두 번째 회기에서는 녹음한 문장으로 따라말하기 과제를 실 시하였다. 연구과제를 하기 전 연습 문제를 통해 문장 따라말하 기 과제에 대해 충분히 이해한 것으로 판단이 되면 본 검사를 시작하였다. 따라말하기 과제는 총 4 개로 아동에게 학습효과가 일어나지 않도록 순서 없이 무작위로 제시하였다. 하나의 따라 말하기 과제는 10 개의 문항으로 구성이 되어 있으며 발화길이 를 변화시킨 과제 1 에서는 짧은 발화와 긴 발화 문장을 각각 5 개로 구성을 했다. 말속도를 변화시킨 과제 2에서 평균보다 $30 \%$ 빠른 말속도 문장 4 개 그리고 평균보다 $30 \%$ 느린 말속도 문장 4 개로 구성하였다. 말속도와 발화길이를 동시에 변화시킨 과제 3 에서 빠르고 짧은 발화 문장 2 개, 빠르고 긴 발화 문장 2 개, 느리고 짧은 발화 문장 2 개, 느리고 긴 발화 문장 2 개로 구성 되어 있다. 그리고 마지막으로 통사적 복잡성과 발화길이를 조 절한 과제 4에서는 단문과 복문 각각 5 개로 구성하였다. 그리고 아동들의 말속도 변화를 가늠하기 위해서 말속도를 변화시킨 과제 2와 과제 3 에서는 평균 말속도 문장 2 개 포함하였다. 연구 과제 1 4번 문장들은 부록에서 볼 수 있다. 아동의 발화는 모두 음성 및 영상 녹음하였다. 시각적 자극이 모방 과제 시 일반적인 대화 상황을 자연스럽게 유도할 수 있다는 선행연구(Armington \& Bloom, 1974; Barnes et al., 1970; Hale-Haniff \& Siegal, 1981; Slobin \& Welsh, 1973)를 근거로, 본 연구에서도 아동들에게 자 연스러운 반응을 유도하기 위하여 파워포인트로 그림을 제시 하였다. 파워 포인트 예시는 그림 1 과 같다.

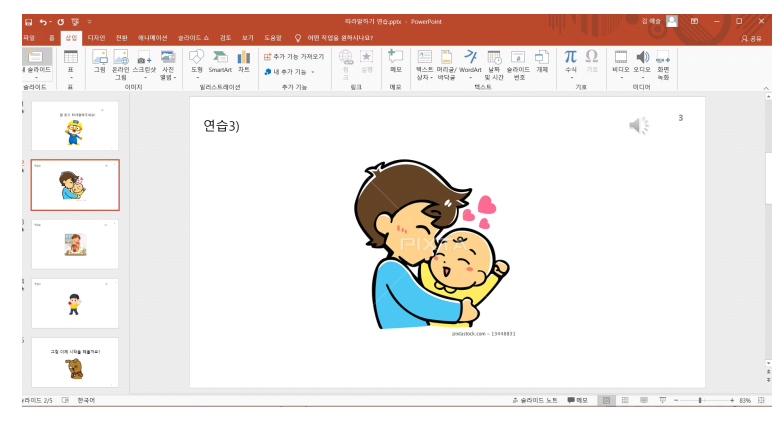

그림 1. 시각적 자극 예시

Figure 1. Example of visual stimuli 


\subsection{2. 문장 따라말하기 과제 제작}

본 연구에서 실험과제로 문장 따라말하기 과제를 사용하였 다. 문장 따라말하기 과제는 자발화에서 통제하기 힘든 외부 요 인들을 통제할 수 있고(Silverman \& Ratner, 1997), 단시간에 언 어학적 구조를 끌어낼 수 있는 효율성(Hale-Haniff \& Siegel, 1981)을 가지고 있다. 따라서 자발화나 모델링 과제보다는 길 이, 속도 그리고 통사론적 변인들을 쉽게 통제하고 변화시킬 수 있어서 이 과제를 선정하였다.

문장 따라말하기 과제의 모든 문장은 4-6세 아동이 구사할 수 있는 문장과 단어, 조음 발달 수준을 최대한 고려하여 한국 어의 주요 문법적인 특징 및 학령전기 아동의 언어발달에 따라 제작하였다. 문장 길이는 언어발달의 측면에서 선행연구들을 보면 2-3세 일반 아동의 평균 문장 길이가 2-3개 정도의 낱말로 이루어져 있는 점을 참고하여 제작하였다. 그리고 일반 아동의 조음 발달 특성에 따라 단어의 조음 복잡성을 고려하여 문장을 제작하였다. 조음 복잡성은 아동의 발달 특성에 맞추어 $\operatorname{Kim}(1996)$ 의 연구를 참고하였다. 이 연구에서 우리말 자음의 발 달 연령을 살펴보면 습득 기준에 따라 출현 연령, 관습적 연령, 숙달 연령, 완전습득 연령으로 나눌 수 있는데 이에 따라/프,ㅁ, 이등의 파열음과 비음은 2세에 완전습득이 가능하고 4-5세에 서/,ㅈㅈ,ㅊ/ 등의 파열음이 완전습득되고 유음/ㄹ/와 마찰음 / 人, ㅆ, 히은 5세 후반에서 6세 정도에 완전히 발달 된다고 서술 되어 있다. 이 서술을 근거로 본 연구의 대상은 평균 연령이 4-5 세임으로 4-6세 조음 발달의 연령에 따라 해당 연령의 아동이 완전 습득 가능한 파열음, 비음과 파찰음을 위주로 단어들을 선 정하였다.

본 연구의 과제 1 인 발화길이를 조절한 문장 따라말하기의 경우 짧은 발화의 길이를 3 개의 낱말(8-9음절), 긴 발화의 길이 를 5 개의 낱말(14음절)로 하였고 통사적 복잡성을 통제하기 위 하여 문장을 모두 단문으로 구성하였다. 말속도와 발화길이를 동시에 변화시킨 과제 3에서도 통사적 복잡성을 고려하여 실험 과제를 제작하였다. 말하자면, 아동의 비유창성이 나타나는 요 인이 통사적 복잡성이 되지 않도록 본 연구대상 아동들의 언어 발달 수준에 맞추어 문장의 길이와 구조를 조절하였다.

과제 2 인 말속도를 조절한 문장 따라말하기 과제의 말속도는 Sim et al.(1999) 연구를 참고하여 아동 자신의 평균 말속도를 기 준으로 가감하여 세 가지 종류(아동 자신의 평균 말속도 보다 빠르게, 아동 자신의 평균 말속도, 아동 자신의 평균 말속도 보 다 느리게)로 분류했다. 아동의 평균 말속도는 아동마다 각자의 말속도를 기준으로 정하였는데 이는 평균 말속도를 전체 아동 의 평균으로 계산하여 문장을 녹음했을 때 각 아동의 언어 수준 에 따라 언어적 부담이 달라서 언어적 부담으로 인해 생기는 변 수가 통제되지 않기 때문이다. 녹음된 문장의 자연스러움을 유 지하기 위하여 말속도를 조절할 때 문장 내 조음을 늘리지 않고 어절 간의 쉼을 조절하였다(Goldman-Eisler, 1968). 또한, 말속도 의 형평성을 주기 위해 Guitar \& Marchinkowski(2001)와 Sim \& Zebrowski(1994)의 연구들을 참고하여 아동의 말속도를 기준으 로 $\pm 50 \%$ 로 조절한 문장 따라말하기 과제를 일반 아동 대상으로
예비실험을 했다. 실험 결과, 말속도의 변화 폭이 너무 커 문장 따라말하기 정확도가 떨어졌다. 그래서 본 연구에서는 말속도 를 $\pm 30 \%$ 로 수정하였다.

그리고 과제 4 인 통사적 복잡성과 발화길이를 조절한 문장 따라말하기의 경우 복문의 음절수는 발화길이를 조절한 과제 1 의 문장에서 긴 발화와 똑같은 13-14음절로 하되 Go \& KoO (2008)을 참고하여 문장 주어와 서술어 관계가 여러 번 나타나 는 이어진 문장으로 만들었다. 복문의 구조는 Kim \& Jeong (2011)을 참고하여 접속문 중에서 2-3세에서 가장 많이 나타나 는 때연결( 하고)을 사용하였다. 또한, 말속도로 인해 말더듬에 영향을 주는 것을 통제하기 위하여 통사적 복잡성 변화 시 말속 도를 아동 자신의 평균 말속도로 통일하였다.

\subsection{3. 비유창성 유형 분석 방법}

문장 따라말하기 과제 수행 시 녹음된 아동의 발화를 비유창 성 유형에 따라 전사 및 분석하였다. 비유창성 유형은 Ambrose \& Yairi(1999)에 근거하여 아동의 비유창성을 분류하였다. 그 중 비정상적 비유창성(Stuttering like difluency, SLD)에 해당하 는 단어 부분 반복(PR), 단음절단어 반복(SR), 비운율적 발성 (DP)(연장, 막힘, 단어 깨짐)의 빈도수를 계산하여 총 SLD 빈도 의 합을 구하였다.

\subsection{4. 통계적 처리}

실험 결과 자료는 SPSS 25.0 프로그램을 이용하여 분석하였 으며, 통계적 처리는 다음과 같다. 문장 따라말하기 과제에서 말속도, 발화길이 및 통사적 복잡성의 변화에 따른 일반아동과 말더듬아동 간의 $\mathrm{SLD}$ 에 차이가 있는가를 검증하기 위해 비모 수 검정(Man Whitney U)을 실시하였다.

\section{3. 연구 결과}

3.1. 발화길이를 변화시킨 과제에서 집단 SLD 빈도 비교 평균 말속도에서 발화길이가 변화함에 따른 일반아동과 말 더듬아동 간 SLD 차이를 알아보기 위해 Man-Whitney U 검정을 실시하였다. 그 결과, 짧은 발화에서 집단 간 유의한 차이가 있 었고 $(Z=-3.187, p<.01)$, 긴 발화에서도 집단 간의 유의한 차이 가 있었다 $(Z=-3.238, p<.01)$. 결과는 표 2와 같다.

표 2. 과제 1 에 따른 집단 간 비유창성 의 SLD 차이 Table 2. Difference in SLD between CWN and CWS in task 1

\begin{tabular}{c|c|c|c|c}
\hline & $\begin{array}{c}\text { CWNS } \\
(\mathrm{n}=9)\end{array}$ & $\begin{array}{c}\text { CWS } \\
(\mathrm{n}=9)\end{array}$ & \multirow{2}{*}{ Z-value } & $p$-value \\
\cline { 2 - 4 } & $\mathrm{M}(S D)$ & $\mathrm{M}(S D)$ & & \\
\hline Short & $0.22(0.44)$ & $1.89(0.93)$ & -3.187 & $.001^{* *}$ \\
\hline Long & $1.56(0.88)$ & $4.33(1.87)$ & -3.238 & $.001^{* *}$ \\
\hline
\end{tabular}

CWNS, children who do not stutter; CWS, children who stutter.

즉, 자신의 평균 말속도로 따라말하기를 했을 때, 말더듬 아 동은 일반아동보다 짧은 발화와 긴 발화에서 더 많은 비유창성 
을 보였다. SLD 빈도의 차이는 그림 2에서 볼 수 있다.

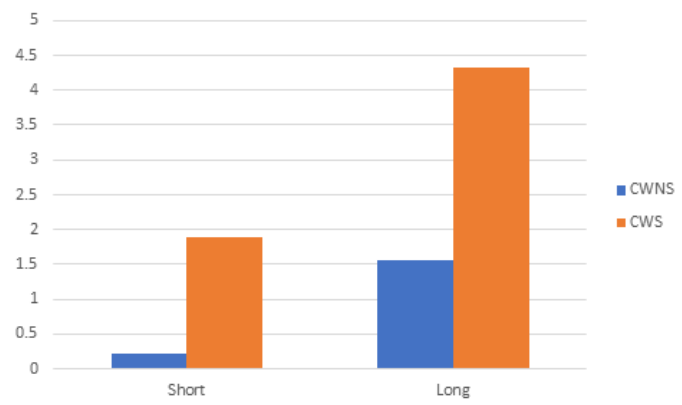

CWNS, children who do not stutter; CWS, children who stutter.

그림 2. 과제 1 에 따른 집단 간 SLD 빈도 차이

Figure 2. Difference in SLD between CWNS and CWS in task 1

3.2. 말속도를 변화시킨 과제에서 집단 간 SLD 비교

말속도 변화에 따라 일반아동과 말더듬아동 간의 비유창성 차이를 알아보기 위해 Man-Whitney U 검정을 실시한 결과, 자 신의 평균 말속도 보다 빠른 말속도에서 집단 간의 유의한 차이 가 있었으나 $(Z=-3.059, p<.01)$, 느린 말속도에서는 집단 간 유 의한 차이가 없었다 $(Z=-1.623, p=.105)$. 결과는 표 3 과 같다.

표 3. 과제 2에서 집단 간 SLD 비교

Table 3. Difference in SLD between CWN and CWS in task 2

\begin{tabular}{c|c|c|c|c}
\hline \multirow{2}{*}{} & $\begin{array}{c}\text { CWNS } \\
(\mathrm{n}=9)\end{array}$ & $\begin{array}{c}\text { CWS } \\
(\mathrm{n}=9)\end{array}$ & \multirow{2}{*}{ Z-value } & $p$-value \\
\cline { 2 - 4 } & $\mathrm{M}(S D)$ & $\mathrm{M}(S D)$ & & \\
\hline Fast & $0.44(0.73)$ & $2.33(1.32)$ & -3.059 & $.002^{* *}$ \\
\hline Slow & $0.44(0.73)$ & $1.22(1.09)$ & -1.623 & .105 \\
\hline
\end{tabular}

CWNS, children who do not stutter; CWS, children who stutter.

즉, 발화길이가 동일한 문장을 빠른 속도로 따라 말하기를 했 을 때, 말더듬 아동은 일반아동보다 더 많은 $\mathrm{SLD}$ 를 보였다. $\mathrm{SLD}$ 빈도의 차이는 그림 3 에서 볼 수 있다.

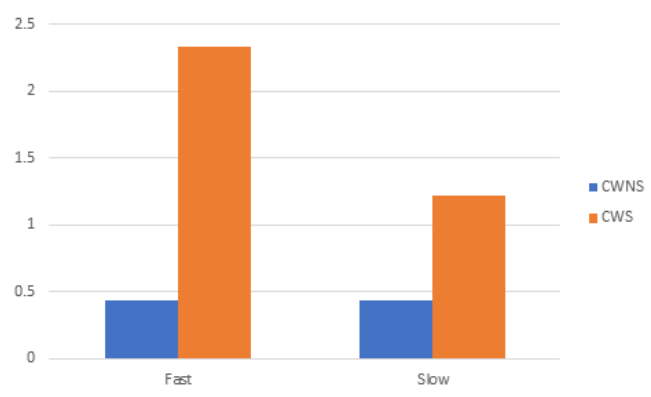

CWNS, children who do not stutter; CWS, children who stutter.

그림 3. 과제 2에서 집단 간 SLD 비교

Figure 3. Difference in SLD between CWNS and CWS in task 2

3.3. 말속도와 발화길이를 변화시킨 과제에서 집단 간 비유창성 빈도 비교

말속도 및 발화길이 변화에 따라 일반아동과 말더듬 아동 간
의 SLD 차이를 알아보기 위해 Man Whitney U 검정을 실시하였 다. 그 결과, 빠른 말속도에서 짧은 문장을 따라말하기를 했을 때 집단 간에 유의한 차이가 있었고 $(Z=-2.753, p<.01)$, 또한 빠 른 말속도에서 긴 문장을 따라말하기를 했을 때 집단 간 유의한 차이가 있었다 $(Z=-2.996, p<.01)$. 즉, 자신의 평균 말속도보다 빠른 말속도로 따라말하기를 했을 때 말더듬 아동 집단은 일반 아동 집단보다 짧은 문장과 긴 문장 모두에서 더 많은 $\mathrm{SLD}$ 를 보 였다.

느린 말속도에서는 짧은 문장을 느린 말속도로 따라말하기 를 했을 경우, 집단 간에 유의한 차이가 없었고 $(Z=-1.579$, $p=114)$, 긴 문장을 느린 말속도로 따라말하기를 했을 때에도 집 단 간에는 유의한 차이가 없었다 $(Z=-1.340, p=180)$. 즉, 자신의 평균 말속도 보다 느리게 따라말하기를 할 경우는 발화길이에 따라 집단 간 차이가 없었다. 통계 결과는 표 4 , 그리고 SLD 차 이는 그림 4에서 볼 수 있다.

표 4. 과제 3에서 집단 간 SLD 비교

Table 4. Difference in SLD between CWNS and CWS in task 3

\begin{tabular}{c|c|c|c|c}
\hline \multirow{2}{*}{} & $\begin{array}{c}\mathrm{CWNS} \\
(\mathrm{n}=9)\end{array}$ & $\begin{array}{c}\mathrm{CWS} \\
(\mathrm{n}=9)\end{array}$ & \multirow{2}{*}{$Z$-value } & $p$-value \\
\cline { 2 - 5 } & $\mathrm{M}(S D)$ & $\mathrm{M}(S D)$ & & \\
\hline Fast-short & $0.22(0.67)$ & $1.11(0.60)$ & -2.753 & $.006^{* *}$ \\
\hline Fast-long & $0.67(0.50)$ & $2.33(1.12)$ & -2.996 & $.003^{* *}$ \\
\hline Slow-short & $0.22(0.44)$ & $0.78(0.83)$ & -1.579 & .114 \\
\hline Slow-long & $0.56(0.73)$ & $1.00(0.71)$ & -1.340 & .180 \\
\hline
\end{tabular}

CWNS, children who do not stutter; CWS, children who stutter.

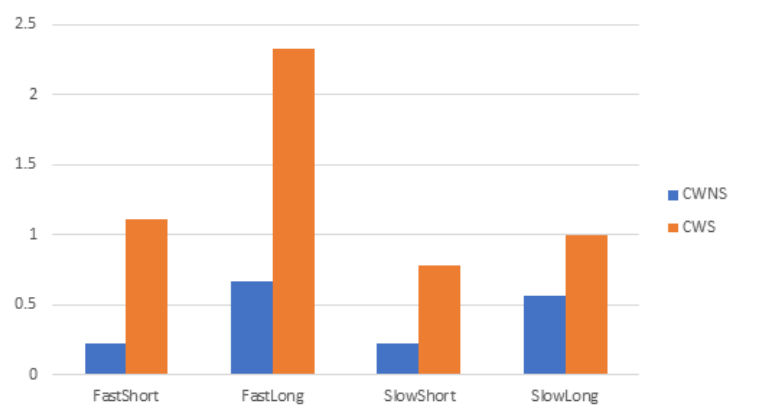

CWNS, children who do not stutter; CWS, children who stutter.

그림 4. 과제 3에서 집단 간 비유창성 비교

Figure 4. Difference in SLD between CWNS and CWS in task 3

3.4. 통사적 복잡성와 발화길이를 변화시킨 과제에서 집단 간 SLD 빈도 비교

통사적 복잡성의 변화에 따라 일반아동과 말더듬 아동 간의 비유창성 빈도수의 차이를 알아보기 위해 비모수 검정 ManWhitney U 검사를 실시하였다. 그 결과 단문에서 집단 간에 유 의한 차이가 있었고 $(\mathrm{Z}=-2.244, p<.05)$ 복문에서도 집단 간에 유 의한 차이가 있었다 $(\mathrm{Z}=-3.098, p<.01)$. 특히 복문에서 말더듬 아동이 일반아동보다 SLD의 빈도가 더 높은 것으로 나타났다. 결과는 표 5 와 같다. 
표 5. 과제 4에서 집단 간 비유창성 비교 Table 5. Difference in disfluency between CWNS and CWS in task 4

\begin{tabular}{c|c|c|c|c}
\hline & $\begin{array}{c}\text { CWNS } \\
(\mathrm{n}=9)\end{array}$ & $\begin{array}{c}\text { CWS } \\
(\mathrm{n}=9)\end{array}$ & \multirow{2}{*}{$Z$-value } & $p$-value \\
\cline { 2 - 4 } & $\mathrm{M}(S D)$ & $\mathrm{M}(S D)$ & & \\
\hline Simple & $0.22(0.44)$ & $1.67(1.66)$ & -2.241 & $.025^{*}$ \\
\hline Complex & $1.11(1.17)$ & $4.33(2.06)$ & $-3,093$ & $.002^{* *}$ \\
\hline
\end{tabular}

CWNS, children who do not stutter; CWS, children who stutter.

즉, 자신의 말속도로 단문과 복문을 따라말하기를 했을 경우 모두에서 말더듬 아동이 일반아동보다 더 많은 SLD를 보였다. 결과는 그림 5 와 같다.

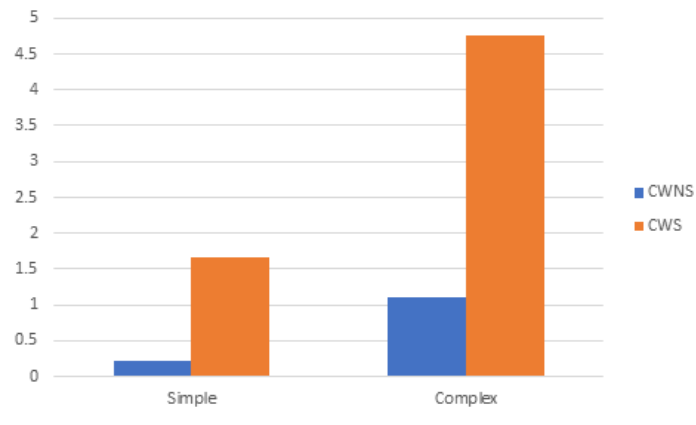

CWNS, children who do not stutter; CWS, children who stutter.

그림 5. 과제 4에서 집단 간 SLD 비교

Figure 5. Difference in SLD between CWNS and CWS in task 4

3.5. 말속도, 발화길이 그리고 통사적 복잡성 변화에 따른 말더듬 아동 개개인의 비유창성 특성

\subsection{1. 발화길이를 변화시킨 과제에서 말더듬 아동 개개인의 비유창성 특성}

과제 1 에서 발화길이를 조절하였을 때 전반적으로 짧은 발화 보다 긴 발화에서 더 많은 SLD를 보였다. 하지만 P201, P202, $\mathrm{P} 206$ 아동은 짧은 발화와 긴 발화에 $\mathrm{SLD}$ 의 수 차이가 크지 않았 고 P203 아동은 짧은 발화와 긴 발화에서 비유창성 빈도수가 같 았다. 따라서 위 아동들은 발화길이의 변화에 큰 영향을 받지 않는 것으로 나타났다. 반면 P205, P207, P208, P209 아동들은 짧은 발화보다 긴 발화에서 SLD가 증가하였기 때문에 긴 발화 에 취약한 것으로 보인다. 그중에서도 P205는 긴 발화에서 가장 높은 SLD 빈도가 나타나 발화길이 변화에 가장 취약한 것으로 보인다. 그리고 P204 아동은 짧은 발화에서는 SLD를 보이지 않 고 긴 발화에서 3회의 $\mathrm{SLD}$ 를 보였다. 이는 P204 아동은 상대적 으로 긴 발화에서 취약한 것을 볼 수 있다. 과제 1 의 아동별 비 유창성 특성은 그림 6과 같다.

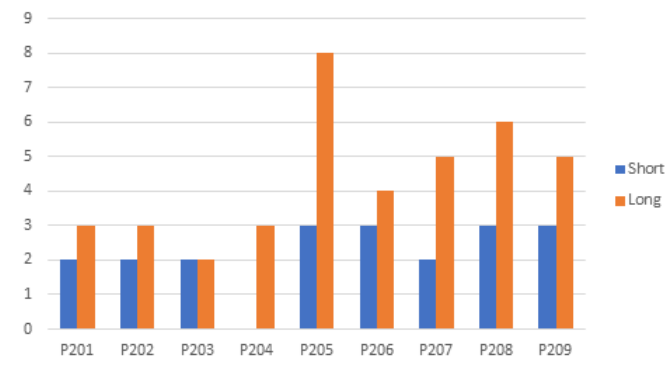

CWS, children who stutter.

그림 6. 과제 1 에서 말더듬 아동의 개별적 비유창성 특성 Figure 6. Disfluency pattern of CWS in task 1

\subsection{2. 말속도를 변화시킨 과제에서 말더듬 아동 개개인의 비유창성 특성}

과제 2에서 말속도를 조절하였을 때, 느린 말속도에서 P201 과 P207 아동은 SLD 빈도가 높게 나타났다. 따라서 P201 아동 과 P207 아동은 자신보다 느린 말속도에 가장 취약한 것으로 나 타났다. 반면에 P202, P203, P204, P205, P206, P208 아동들은 빠 른 말속도에서 더 많은 SLD 빈도를 보였고 그중에서도 P205 아 동은 가장 많은 SLD 빈도를 보였다. P209 아동은 느린 말속도와 빠른 말속도에서 모두 높은 SLD 빈도가 나타났기 때문에 말속 도의 변화에 취약한 것으로 보인다. 과제 2 에서 각 아동별 비유 창성 특징은 그림 7과 같다.

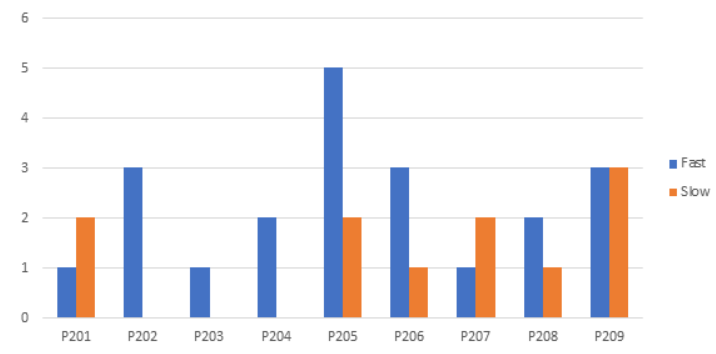

CWS, children who stutter.

그림 7. 과제 2 에서 말더듬 아동의 개별적 비유창성 특성

Figure 7. Disfluency pattern of CWS in task 2

\subsection{3. 말속도와 발화길이를 변화시킨 과제에서 말더듬 아동 개개인의 비유창성 특성}

과제 3에서 말속도와 발화길이를 조절하였을 때, P201 아동 은 빠른 말속도에 짧은 발화, 빠른 말속도에 긴 발화에 모두 취 약한 것으로 보인다. P202, P203, P205, P208과 P209 아동은 빠 른 말속도와 긴 발화에서 많은 SLD가 나타났다. 특히 P208 아동 이 빠르고 긴 발화에서 가장 높은 빈도의 $\mathrm{SLD}$ 를 보였다. 즉 이 들은 동시다발적인 언어 자극(빠른 말속도, 긴 발화)에 취약한 것으로 보인다. P204, P206 아동들은 빠른 말속도에서 짧은 발 화와 긴 발화 모두 똑같은 SLD 빈도가 나타나서 발화길이보다 말속도의 변화에 더 취약한 것으로 보인다. 반면 P207 아동은 느리고 짧은 발화에서 가장 많은 SLD가 나타나 느린 말속도 상 황에 어려움이 있는 것으로 보인다. 과제 3에서 아동별 비유창 
성 특징은 그림 8 과 같다.

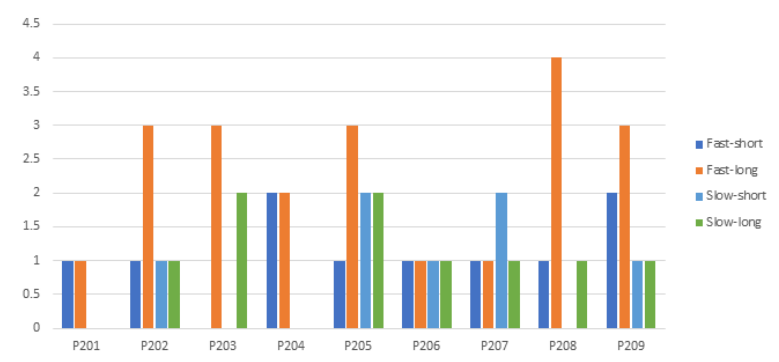

CWS, children who stutter.

그림 8. 과제 3에서 말더듬 아동의 개별적 비유창성 특성 Figure 8. Disfluency pattern of CWS in task 3

\subsection{4 통사적 복잡성과 발화길이를 변화시킨 과제 4에서 말더듬 아동 개개인의 비유창성 특성}

과제 4에서 통사적 복잡성과 발화길이를 조절했을 때, P201, P202, P204, P205 그리고 P207 아동은 단문보다 복문에서 SLD 빈도가 더 크게 나타나 복문에 취약한 것으로 보인다. P203 아 동은 단문과 복문 모두 SLD 빈도가 높게 나타나지 않았다. 즉, P203 아동은 통사적 복잡성 변화에 취약하지 않은 것으로 보인 다. 반면에 P206과 P209 아동은 단문과 복문에서 SLD 차이가 나타나지 않았고 P208 아동은 단문과 복문 모두 높은 SLD가 나 타났다. 그러므로 이 아동들의 비유창성 특성은 통사적 복잡성 의 변화가 아닌 다른 요인으로 인해 나타난 것으로 보인다. 과 제 4에서 아동별 비유창성 특징은 그림 9와 같다.

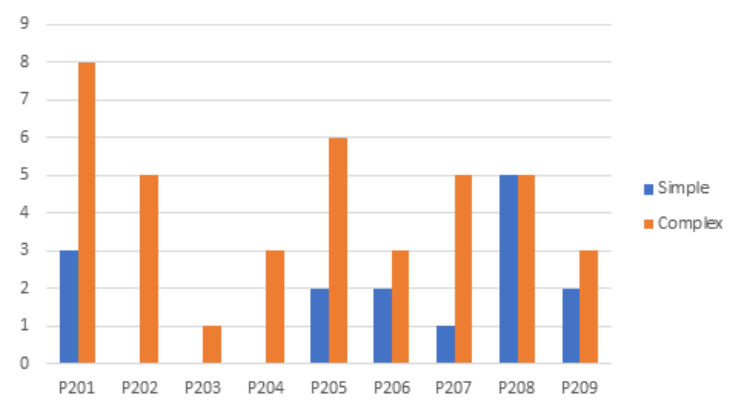

CWS, children who stutter.

그림 9. 과제 4에서 말더듬 아동의 개별적 비유창성 특성 Figure 9. Disfluency pattern of CWS in task 4

\section{4. 논의 및 결론}

본 연구의 목적은 말속도, 발화길이 및 통사적 복잡성을 동시 에 체계적으로 변화시켜서 문장 따라말하기 과제를 시행했을 때, 말더듬 아동 집단과 일반아동 집단의 SLD의 빈도를 비교 분 석하는 것이다. 본 연구의 결과를 요약하면 다음과 같다. (1) 발 화길이를 변화시킨 과제에서 말더듬 아동은 발화길이에 상관 없이 일반아동보다 더 많은 $\mathrm{SLD}$ 를 보였고 반면 일반아동은 $\mathrm{SLD}$ 를 거의 보이지 않았다. (2) 말속도를 변화시킨 과제에서 말
더듬 아동은 일반아동보다 빠른 말속도에서더 많은 SLD를 보 였다. (3) 말속도와 발화길이를 동시에 변화시킨 과제에서 빠른 말속도의 문장을 따라말하기를 했을 때는, 말더듬 아동 집단은 일반아동 집단보다 짧은 문장과 긴 문장 모두에서 더 많은 SLD 를 보였다. (4) 통사적 복잡성과 발화길이를 변화시킨 과제에서 단문과 복문 모두에서 말더듬 아동이 일반아동보다 더 많은 $\mathrm{SLD}$ 를 보였다. 마지막으로 (5) 말더듬 아동 개개인의 비유창성 특성을 분석한 결과, 대부분 아동들이 통계 결과와 비슷했으나 이와는 다른 양상을 보인 아동들도 있었다. 위에서 언급한 연구 결과의 순서에 따라 논의하면 다음과 같다.

첫째, 발화길이를 변화시킨 과제에서 두 집단 간 비유창성 차 이를 분석했을 때, 말더듬 아동은 발화길이와 상관없이 일반아 동보다 더 많은 비유창성을 보였다. 이러한 결과로 미루어볼 때 따라말하기 과제에서 발화길이에 따라 SLD의 빈도가 유의하게 변하지 않았다. 그렇지만 일반아동보다는 훨씬 더 많은 SLD를 보이는 것은 사실이다. 말더듬 아동들이 일반아동과 비교했을 때 평균 말속도로 따라하는 문장 따라말하기에서 유의하게 더 많은 SLD를 산출한 이유는 말더듬 아동이 일반아동보다 음운 부호화 능력과 음운인식 측면에서 미세한 차이에 기인한다고 추론할 수 있다. 학령전기 말더듬 아동과 일반아동의 음운부호 화 능력을 무의미 단어의 반복을 통해 분석한 Hakim \& Ratner (2004)에 의하면 3음절 무의미 단어 반복을 할 때 정확도에서 두 집단 간 유의미한 차이가 있었다. 이러한 집단 간의 정확도 차 이는 말더듬 아동이 무의미 단어의 연속적인 음운배열을 잠시 기억했다가 다시 정확하게 배열순서대로 산출하는 능력이 결 핍된 것에서 찾을 수 있다고 보았다. 한편 학령전기 말더듬 아 동과 일반아동의 이름대기 능력을 비교한 Lee et al.(2012)의 연 구에 따르면 이름대기 과제의 정확률에서 집단 간 유의미한 차 이가 없었으나, 말더듬 아동집단의 반응시간이 일반아동 집단 보다 유의하게 길었다. 또한, 말더듬 아동과 일반아동의 음운인 식 능력을 비교한 Pelczarski \& Yaruss(2014)의 연구에 따르면 조 음능력, 수용언어 및 표현언어에서는 집단 간 차이가 없었으나 말더듬 아동의 음운인식 점수가 일반아동의 점수보다 낮았다 고 한다. 하지만 말더듬 아동의 누구도 $-1 \mathrm{SD}$ 의 수준에 있지 않 았다고 한다.

그리고 평균 말속도에서 문장 따라말하기를 했을 때 일반아 동은 $\mathrm{SLD}$ 를 거의 보이지 않았으나, 말더듬 아동 집단은 긴 문장 에서 많은 SLD를 보였다. 이러한 연구 결과는 일반적으로 예측 되는 결과이다. 왜냐하면, 긴 문장에 비해 짧은 문장을 따라 말 할 때 아동의 작업기억에 부과되는 요구가 상대적으로 낮아서 문장의 오류가 덜 나타난다(Bonvillian et al., 1979). 그리고 본 연 구의 이러한 결과는 앞에서 이미 언급한 바와 같이, 같은 발달 기에 있는 일반아동들보다 말더듬 아동이 음운 부호화를 정상 적으로 실행하기 위해 요구되는 음운기억에서 더 많은 어려움 을 보인다는 선행연구(Hakim \& Ratner, 2004)에 의해 설명될 수 있다.

둘째, 말속도를 변화시킨 과제 2에서 빠른 말속도로 따라 말 할 때, 말더듬 아동은 일반아동보다 더 많은 SLD 빈도를 보였 
다. 이는 요구용량 모델에 따라 말더듬 아동은 자신의 말운동 처리능력보다 더 과중한 과제가 주어졌을 때 SLD가 증가한다 고 볼 수 있다. 즉, 빠른 말속도를 따라 말하려고 할 때 아동의 언어처리 능력에 과부하가 걸려 SLD가 나타날 수 있다는 것이 다. 따라서 부모의 빠른 말속도가 아동의 유창성에 부정적인 영 향을 미친다는 연구와도 일치하는 결과라고 볼 수 있다(Conture, 1990).

셋째, 말속도와 발화길이를 변화시킨 과제에서 빠른 말속도 의 문장을 따라말하기를 했을 때 말더듬아동 집단은 일반아동 집단보다 짧은 문장과 긴 문장 모두에서 더 많은 $\mathrm{SLD}$ 를 보였다. 특히 말더듬 아동의 경우, 빠르고 긴 문장을 따라 말했을 때의 SLD 빈도가 2.3 개로 수준으로 높은 SLD 빈도를 보였다. 이러한 결과는 빠른 말속도와 긴 발화에서 SLD가 유의하게 높게 나타 난다는 것을 보여준다. 또한, 본 연구의 결과는 말더듬 아동의 자발화를 비교하여 분석하였을 때 비유창성이 있는 발화는 더 길고 복잡하다는 Yaruss et al.(1999)의 연구 결과와 일치한다고 볼 수 있다. 한편 이러한 연구 결과는 말더듬 아동의 음운 작업 기억이 같은 발달기에 있는 일반아동들보다 낮다는 선행연구 들로도 설명될 수 있다(Anderson \& Wagovich, 2010; Anderson et al., 2006; Spencer \& Weber-fox, 2014). 최근 Pelczarski \& Yaruss (2016)가 말더듬 아동과 일반아동들의 음운기억 능력(phonological memory)을 비단어 따라말하기 과제(nonword repetition)로 실험 한 결과 말더듬 아동들의 음운기억 능력은 일반아동보다 매우 낮다고 보고하였다. 이와 같은 선행연구들의 결과와 요구용량 모델의 측면에서 보면, 다른 상황에 비해 빠른 말속도의 긴 문 장을 따라 말할 때 가장 많은 SLD가 발생한다는 것을 예측할 수 있다. 그 이유를 요구-용량 모델의 관점에서 살펴보면 말더듬 아동은 일반아동보다 말운동 조절, 음운해독 및 작업기억, 언어 처리 능력에 심한 과부하가 걸렸기 때문이라고 파악된다.

또한, 느린 말속도의 문장을 따라말하기 했을 때, 유의한 차 이를 보이지 않았지만 말더듬 아동과 일반아동 모두 자신의 말 속도보다 느린 말속도에서 좀 더 많은 SLD 빈도를 보였다. 이는 아동의 발화가 길어지고 말속도가 느려지면 아직 발달기에 있 는 학령전기 아동들이기 때문에 말운동 통제 능력이 미숙해서 빠른 말속도 만큼이나 쉽지 않기 때문이다. Sim \& Zebrowski (1994) 연구의 결과에 의하면 아동들은 자신과 유사한 말속도 보다 빠르거나 유사한 말속도에 비해 느린 말속도를 따라하는 것에 더 많은 어려움을 보인다고 한다. 말더듬 아동이 일반아동 보다 느린 발화에서 조금 더 많은 SLD 빈도를 보이는 것은 말더 듬 아동들의 말운동 통제능력이 일반아동보다조금더 미숙하 기 때문으로 보인다.

본 연구의 결과는 말속도 변화에 발화길이의 변화가 복합적 으로 작용하면, 말더듬 아동의 말운동 처리 능력과 음운 작업기 억 용량을 초과하여 훨씬 더 많은 SLD가 나타난 것으로 볼 수 있다. 따라서, 치료사와 부모가 과하게 느리거나 빠른 말속도가 아닌 아동 자신과 유사한 말속도 그리고 아동이 처리할 수 있을 정도의 짧은 발화로 말하는 것이 아동의 유창성 증진에 도움을 준다는 것을 시사한다.
넷째, 본 연구에서 통사적 복잡성과 발화길이를 변화시킨 과 제에서 평균 말속도로 문장을 따라말할 때, 모든 문장에서 말더 듬 아동이 일반아동보다 더 많은 SLD를 보였으나 복문에서는 말더듬 아동의 SLD가 더 유의하게 차이가 나는 모습을 보였다. 이는 말더듬 아동은 일반아동보다 통사적으로 복잡한 문장에 서 음운해독과 작업기억에 과부하가 더 걸리기 때문이라고 추 론할 수 있다. 즉, 부족한 음운 작업기억 능력이 집중력, 음운해 독, 말운동 조절능력 요인들과 함께 말더듬 아동의 말운동 체계 의 불안정(unstability)에 영향을 미치는 요인이 되는 것이다 (Smith \& Kelly, 1997; Smith et al., 2012). 또한 본 연구 결과를 통 해 발화길이가 길고 통사적 복잡성이 증가하였을 때 말더듬 아 동은 일반아동보다 더 많은 $\mathrm{SLD}$ 를 보인다는 것을 알 수 있다

\section{(Bernstein Ratner \& Sih, 1987).}

마지막으로 본 연구는 말더듬 아동 개개인의 비유창성 특성 을 살펴보았다. Adams(1990)은 아동의 비유창성이 발생하려면 아동에 대한 요구가 아동의 용량에 비해 어느 정도로 커야만 하 는가에 대한 질문에 대한 답으로, 비유창성을 유발하는 요구와 용량의 불일치 정도는 아동 개인마다 다르다고 주장하였다. 본 연구 결과에서도 아동 개개인의 비유창성 특성을 봤을 때 대부 분의 아동들은 비슷한 특성을 보였으나, 소수의 아동들은 다른 양상을 보였다. 예를 들면, 과제 1 에서 대다수 아동과는 달리 일 부 아동은 짧은 발화와 긴 발화 두 문장에서 모두 낮은 SLD를 보였다. 과제 2에서 어떤 아동은 말속도 변화에 따라 SLD가 변 화하지 않는 아동들도 있었고, 또 다른 아동은 빠른 말속도보다 느린 말속도에서 더 많은 SLD를 보였으며 빠른 말속도와 느린 말속도 모두에서 높은 SLD를 보인 아동도 있었다. 과제 3 에서 는 한 아동은 느리고 짧은 발화에서 더 많은 SLD를 보였고, 빠 르고 짧은 발화, 빠르고 긴 발화에서 차이가 없는 아동들도 있 었다. 과제 4에서는 통사적 복잡성 변화에 따라 SLD 빈도수가 변화하지 않은 아동들도 있었고 단문 복문 모두 SLD 빈도가 낮 은 아동도 있었으며 반대로 단문 복문 모두 높은 SLD를 보인 아 동도 있었다. 즉, 모든 말더듬 아동이 말속도, 발화길이 및 통사 적 복잡성의 증가에 비슷한 정도의 SLD 빈도를 보이지는 않았 다. 이러한 특성은 각 아동이 감당할 수 있는 언어처리 능력, 말 운동 조절능력, 음운해독 및 작업기억 능력의 차이에 따라 무작 위로 나타난 현상으로서 말더듬 아동의 비유창성 패턴을 정확 하게 예측할 수 없다고 할 수 있다.

본 연구에 참여한 말더듬 아동의 수용언어 능력, 표현언어 능 력 및 구문 - 의미이해력이 정상범위에 속하는 아동들이기 때 문에 이 아동들이 SLD를 보이는 것은 언어능력의 문제만은 아 닐 것이다. 실제로 지속적으로 말을 더듬는 아동들의 다수가 평 균 이상의 언어능력을 가지고 있다고 알려져 있다(Watkins, 2005; Watkins \& Yairi, 1997). 또한, 본 연구의 대상인 학령전기 아동들은 말속도에 영향을 주는 말운동 통제능력(speech motor control ability)이 아직 발달과정에 있는 상태이다(Song \& Sim, 2008). 한편 초기 말더듬 아동의 경우 비유창성 정도가 일정한 것이 아니라 주기적으로 호전과 악화가 반복하여 나타나기도 한다. 따라서 실제 임상에서 학령전기 말더듬 아동을 진단하고 
치료하기 위해서는, 말속도를 포함한 말운동 영역과 발화길이 및 통사적 복잡성이 포함된 언어영역뿐만 아니라, 요구-용량 모 델에서 제시하고 있는 인지적, 정서적 측면에서 요구-용량 간의 불균형이 있는가를 주의 깊게 확인할 필요가 있다. 이를 위해서 는 언어치료사, 부모, 교사 및 아동 사이에 유기적인 협력관계 수립이 필수적으로 요구된다.

본 연구는 일반아동과 말더듬 아동 각각 9명을 대상으로 실 시되었기에 연구 결과를 일반화하는 데는 많은 제약이 따른다. 또한, 본 연구에서 제작한 과제의 난이도가 연령에 비해 쉬워 예상한 것보다 말더듬 아동들에게 $\mathrm{SLD}$ 의 빈도수가 덜 나타났 다고 판단된다. 따라서 후속연구에서는 연구대상 아동 수를 늘 리고 과제의 난이도가 아동의 연령에 적합하게 조절되면, 더 유 의한 결과를 도출할 수 있으리라 판단된다.

\section{References}

Adams, M. R. (1990). The demands and capacities model I: Theoretical elaborations. Journal of Fluency Disorders, 15(3), 135-141.

Ainsworth, S., \& Fraser, J. (1998). If your child stutters: A guide for parents (3rd ed.) Memphis, TN: The Stuttering Foundation of America.

Anderson, J. D., \& Wagovich, S. A. (2010). Relationships among linguistic processing speed, phonological working memory, and attention in children who stutter. Journal of Fluency Disorders, 35(3), 216-234.

Anderson, J. D., Wagovich, S. A., \& Hall, N. E. (2006). Nonword repetition skills in young children who do and do not stutter. Journal of Fluency Disorders, 31(3), 177-199.

Ambrose, N. G., \& Yairi, E. (1999). Normative disfluency data for early childhood stuttering. Journal of Speech, Language, and Hearing Research, 42(4), 895-909.

Armington, J. C., \& Bloom, M. B. (1974). Relations between the amplitudes of spontaneous saccades and visual responses. Journal of the Optical Society of America, 64(9), 1263-1271.

Barnes, P. J., Smith, L. M., \& Latto, R. M. (1970). Orientation to visual stimuli and the superior colliculus in the rat. Quarterly Journal of Experimental Psychology, 22(2), 239-247.

Bernstein Ratner, N. (1997). Linguistic behaviors at the onset of stuttering. In B. Maassen \& P. Van Lieshout (Eds.), Speech motor control: New developments in basic and applied research (pp. 585-593). Oxford, UK: Oxford University Press.

Bernstein-Ratner, N., \& Sih, C. C. (1987). Effects of gradual increases in sentence length and complexity on children's dysfluency. Journal of Speech and Hearing Disorders, 52(3), 278-287.

Bonvillian, J. D., Raeburn, V. P., \& Horan, E. A. (1979). Talking to children: The effects of rate, intonation, and length on children's sentence imitation. Journal of Child Language, 6(3), 459-467.
Bosshardt, H. G. (2006). Cognitive processing load as a determinant of stuttering: Summary of a research programme. Clinical Linguistics \& Phonetics, 20(5), 371-385.

Conture, E. G. (1990). Stuttering (2nd ed.). Englewood Cliffs, NJ: Prentice-Hall.

Curlee, R. F. (2000). Demands and capacities versus demands and performance. Journal of Fluency Disorders, 25(4), 329-336.

Gaines, N. D., Runyan, C. M., \& Meyers, S. C. (1991). A comparison of young stutterers' fluent versus stuttered utterances on measures of length and complexity. Journal of Speech, Language, and Hearing Research, 34(1), 37-42.

Go, Y., \& Koo, B. (2008). Korean grammer. Seoul, Korea: Jipmundang. Goldman-Eisler, F. (1968). Psycholinguistics: Experiments in spontaneous speech. London, UK: Academic Press.

Gottwald, S. R. (2010). Stuttering prevention and early intervention: A multidimensional approach. In Guitar, B., \& McCauley, R. J. (Eds.), Treatment of stuttering: Established and emerging Interventions (pp. 91-117). Baltimore, MD: Lippincott Williams \& Wilkins.

Guitar, B., \& Marchinkoski, L. (2001). Influence of mothers' slower speech on their children's speech rate. Journal of Speech, Language, and Hearing Research, 44(4), 853-861.

Hakim, H. B., \& Ratner, N. B. (2004). Nonword repetition abilities of children who stutter: An exploratory study. Journal of Fluency Disorders, 29(3), 179-199.

Hale-Haniff, M., \& Siegel, G. M. (1981). The effect of context on verbal elicited imitation. Journal of Speech and Hearing Disorders, 46(1), 27-30.

Howell, P., \& Au-Yeung, J. (2007). Phonetic complexity and stuttering in Spanish. Clinical Linguistics \& Phonetics, 21(2), 111-127.

Kelly, E. M., \& Conture, E. G. (1992). Speaking rates, response time latencies, and interrupting behaviors of young stutterers, nonstutterers, and their mothers. Journal of Speech, Language, and Hearing Research, 35(6), 1256-1267.

Kim J. S., \& Jeong S. M. (2011). Sentence repetition performance according to length and structure of sentences in 3 to 5 year-old children. Journal of Speech-Language \& Hearing Disorders, 20(2), 19-36.

Kim,Y. T. (1996). A study on the accuracy of consonants in preschool children using shadow tone test. Communication Sciences \& Disorders, 1(1), 7-34.

Kim, Y. T., Hong, G. H., Kim, K. H., Jang, H. S., \& Lee, J. Y. (2009). Receptive \& expressive vocabulary test (REVT). Seoul, Korea: Seoul Community Rehabilitation Center.

Lee, K. J., Shin, J. C., Kim, H. H., \& Sim, H. S. (2003). The effects of changes of speech rate on the frequency of stutters in pre-school stuttering children. Communication Sciences \& Disorders, 8(3), 
134-148.

Lee, S.Y., Sim, H. S., Shin, M. J., \& Lee, S. B. (2012). A comparison of the ability to wait for names of children who stutter before school age and ordinary children according to articulation complexity. Speech and Hearing Impairment Research, 17(2), 219-233.

Marinis, T., \& Armon-Lotem, S. (2015). Sentence repetition. In S. Armon-Lotem, J. de Jong, \& N. Meir (Eds.), Assessing multilingual children: Disentangling bilingualism from language impairment (pp. 95-124). Bristol, UK: Multilingual Matters.

Pae, S., Lim, S. S., Lee, J. H., \& Jang, H. S. (2004). Korean sentence comprehension test (KOSECT). Seoul, Korea: Seoul Community Rehabilitation Center.

Pelczarski, K. M., \& Yaruss, J. S. (2014). Phonological encoding of young children who stutter. Journal of Fluency Disorders, 39, 12-24.

Pelczarski, K. M., \& Yaruss, J. S. (2016). Phonological memory in young children who stutter. Journal of Communication Disorders, 62, 54-66.

Sawyer, J., Chon, H. C., \& Ambrose, N. G. (2008). Influences of rate, length, and complexity on speech disfluency in a single-speech sample in preschool children who stutter. Journal of Fluency Disorders, 33(3), 220-240.

Sim, H. S., Kim, S. J., Lee, H. R., \& Kim, J. M. (1999). The imitating ability of speaking rates in 4-5 year old children. Speech Science, 5(1), 141-149.

Sim, H. S., \& Zebrowski, P. (1994). The ability of young children to imitate different speaking rates. Journal of Fluency Disorders, 19(3), 210

Sim, H. S., Shin, M. J., \& Lee, E. J. (2011). Paradise-fluency assessment II. Seoul, Korea: Paradise Welfare-Foundation.

Silverman, S. W., \& Ratner, N. B. (1997). Syntactic complexity, fluency, and accuracy of sentence imitation in adolescents. Journal of Speech, Language, and Hearing Research, 40(1), 95-106.

Slobin, D. I., \& Welsh, C. A. (1973). Elicited imitation as a research tool in developmental psycholinguistics. Berkeley, CA: University of California.

Smith, A., Goffman, L., Sasisekaran, J., \& Weber-Fox, C. (2012). Language and motor abilities of preschool children who stutter: Evidence from behavioral and kinematic indices of nonword repetition performance. Journal of Fluency Disorders, 37(4), 344358.

Smith, A., \& Kelly, E. (1997). Stuttering: A dynamic, multifactorial model. In R. F. Curlee, \& G. M. Siegel (Eds.), Nature and treatment of stuttering: New directions (2nd ed., pp. 204-217). Boston, MA: Allyn \& Bacon.

Song, Y. K., \& Sim, H. S. (2008). Compensation ability in speech motor control in children with and without articulation disorders.
Speech Sciences, 15(3), 183-201.

Spencer, C., \& Weber-Fox, C. (2014). Preschool speech articulation and nonword repetition abilities may help predict eventual recovery or persistence of stuttering. Journal of Fluency Disorders, 41, 32-46.

Starkweather, C. W., \& Gottwald, S. R. (2000). The demands and capacities model: Response to siegel. Journal of Fluency Disorders, 25(4), 369-375.

Starkweather, C. W., Gottwald, S. R., \& Halfond, M. M. (1990). Stuttering prevention: A clinical method. Englewood Cliffs, NJ: Prentice Hall.

Watkins, R. (2005). Language abilities of young children who stutter. In E. Yairi, \& N. G. Ambrose (Eds.), Early childhood stuttering: For clinicians by clinicians (pp. 235-252). Austin, TX: Pro-Ed.

Watkins, R. V., \& Yairi, E. (1997). Language production abilities of children whose stuttering persisted or recovered. Journal of Speech, Language, and Hearing Research, 40, 385-399.

Yaruss, J. S. (1999). Utterance length, syntactic complexity, and childhood stuttering. Journal of Speech, Language, and Hearing Research, 42(2), 329-344.

Yaruss, J. S., Newman, R. M., \& Flora, T. (1999). Language and disfluency in nonstuttering children's conversational speech. Journal of Fluency Disorders, 24(3), 185-207.

Zackheim, C. T., \& Conture, E. G. (2003). Childhood stuttering and speech disfluencies in relation to children's mean length of utterance: A preliminary study. Journal of Fluency Disorders, 28(2), 115-142.

Zebrowski, P. M., Weiss, A. L., Savelkoul, E. M., \& Hammer, C. S. (1996). The effect of maternal rate reduction on the stuttering, speech rates and linguistic productions of children who stutter: Evidence from individual dyads. Clinical Linguistics \& Phonetics, 10(3), 189-206.

- 김예슬 (Yesul Kim)

이화여자대학교 언어병리학과 석사과정

서울시 서대문구 이화여대길 52

Tel: 02-3277-3538

Email: jdms3423@naver.com

관심분야: 유창성 장애, 말운동 장애

- 심현섭 (Hyunsub Sim) 교신저자

이회여자대학교 언어병리학과 교수

서울시 서대문구 이화여대길 52

Tel: 02-3277-3538

Email:simhs@ewha.ac.kr

관심 분야: 유창성 장애, 말운동 장애 
부록 1. 말더듬 아동 중증도 및 치료 기간

\begin{tabular}{c|c|c|c|c}
\hline 번호 & 성별 & 중증도 & P-FA 백분위 점수 & 치료기간 \\
\hline 101 & 남 & 중간 & $61 \%-70 \%$ ile & 1 년 미만 \\
\hline 102 & 남 & 심함 & $81 \%-90 \%$ ile & $\mathrm{X}$ \\
\hline 103 & 남 & 중간 & $51 \%-60 \%$ ile & $\mathrm{X}$ \\
\hline 104 & 남 & 중간 & $41 \%-50 \%$ ile & $\mathrm{X}$ \\
\hline 105 & 남 & 심함 & $81 \%-90 \%$ ile & $\mathrm{X}$ \\
\hline 106 & 남 & 중간 & $71 \%-80 \%$ ile & $\mathrm{X}$ \\
\hline 107 & 남 & 중간 & $71 \%-80 \%$ ile & $\mathrm{X}$ \\
\hline 108 & 여 & 중간 & $71 \%-80 \%$ ile & 1 년 미만 \\
\hline 109 & 남 & 심함 & $81 \%-90 \%$ ile & $\mathrm{X}$ \\
\hline
\end{tabular}

\section{부록 2. 과제 1(발화길이 변화)}

\begin{tabular}{c|c|c|c}
\hline 번호 & 음절 & 말속도 & 문장 \\
\hline 1 & 9 & 평균 & 아빠가 자동차를 타요. \\
\hline 2 & 9 & 평균 & 엄마가 아기를 안아요. \\
\hline 3 & 9 & 평균 & 오빠가 사과를 먹어요. \\
\hline 4 & 8 & 평균 & 언니가 가방을 사요. \\
\hline 5 & 9 & 평균 & 아이가 과자를 먹어요. \\
\hline 6 & 13 & 평균 & 뚱뚱한 아빠가 큰 자동차를 타요. \\
\hline 7 & 13 & 평균 & 예쁜 엄마가 우는 아기를 안아요. \\
\hline 8 & 12 & 평균 & 배고픈 오빠가 빨간 사과를 먹어요. \\
\hline 9 & 12 & 평균 & 예쁜 언니가 노란 가방을 사요. \\
\hline 10 & 12 & 평균 & 작은 아이가 큰 과자를 먹어요. \\
\hline
\end{tabular}

\section{부록 3. 과제 2(말속도 변화)}

\begin{tabular}{c|c|c|c}
\hline 번호 & 음절 & 말속도 & 문장 \\
\hline 1 & 8 & 평균 & 엄마가 뽀뽀를 해요. \\
\hline 2 & 9 & 평균 & 아빠가 아기를 안아요. \\
\hline 3 & 9 & 평균 +30 & 아기가 우유를 마셔요. \\
\hline 4 & 9 & 평균 +30 & 오빠가 사탕을 먹어요. \\
\hline 5 & 8 & 평균 -30 & 언니가 연필을 사요. \\
\hline 6 & 9 & 평균 -30 & 누나가 빵을 만들어요. \\
\hline 7 & 9 & 평균 +30 & 오빠가 사과를 먹어요. \\
\hline 8 & 9 & 평균 +30 & 언니가 자전거를 타요 \\
\hline 9 & 9 & 평균 -30 & 이모가 머리를 잘라요 \\
\hline 10 & 9 & 평균 -30 & 오빠가 그네를 밀어요. \\
\hline
\end{tabular}

부록 4. 과제 3(말속도와 발화길이 변화)

\begin{tabular}{c|c|c|c}
\hline 번호 & 음절 & 말속도 & 문장 \\
\hline 1 & 9 & 평균 +30 & 엄마가 우유를 마셔요. \\
\hline 2 & 9 & 평균 +30 & 언니가 아기를 안아요. \\
\hline 3 & 9 & 평균 -30 & 오빠가 자전거를 타요. \\
\hline 4 & 8 & 평균 -30 & 언니가 가방을 사요. \\
\hline 5 & 8 & 평균 & 할머니가 말을 타요. \\
\hline 6 & 13 & 평균 +30 & 작은 엄마가 하얀 우유를 마셔요. \\
\hline 7 & 12 & 평균 +30 & 예쁜 언니가 우는 아기를 안아요. \\
\hline 8 & 13 & 평균 -30 & 작은 오빠가 빨간 자전거를 타요. \\
\hline 9 & 12 & 평균 -30 & 예쁜 언니가 파란 가방을 사요. \\
\hline 10 & 13 & 평균 & 뚱뚱한 할머니가 작은 말을 타요. \\
\hline \multicolumn{4}{r}{}
\end{tabular}

부록 5. 과제 4(통사적 복잡성과 발화길이 변화)

\begin{tabular}{c|c|c|c|c}
\hline 번호 & 음절 & 말속도 & 문장 & 문장 \\
\hline 1 & 9 & 평균 & 단문 & 엄마가 국수를 먹어요. \\
\hline 2 & 9 & 평균 & 단문 & 언니가 이빨을 닦아요. \\
\hline 3 & 9 & 평균 & 단문 & 누나가 주스를 마셔요. \\
\hline 4 & 8 & 평균 & 단문 & 언니가 세수를 해요. \\
\hline 5 & 8 & 평균 & 단문 & 이모가 빵을 만들어요. \\
\hline 6 & 13 & 평균 & 복문 & 엄마가 국수를 먹고 물을 마셔요. \\
\hline 7 & 12 & 평균 & 복문 & 언니가 이빨을 닦고 세수를 해요. \\
\hline 8 & 13 & 평균 & 복문 & 누나가 주스를 마시고 빵을 먹어요. \\
\hline 9 & 12 & 평균 & 복문 & 언니가 세수를 하고 옷을 입어요. \\
\hline 10 & 13 & 평균 & 복문 & 이모가 빵을 만들고 커피를 마셔요 \\
\hline
\end{tabular}




\title{
문장 따라말하기에서 말속도, 발화길이 및 통사적 복잡성에 따른 말더듬 아동과 일반아동의 비유창성 비교
}

\author{
김 예 슬·심 현 섭 \\ 이화여자대학교 언어병리학과
}

\begin{abstract}
국문초록
요구용량 모델에 의하면 말더듬 아동의 비유창성은 외적, 내적 환경에 영향을 받아 나타나는 것으로 알려져 있다. 본 연구의 목적은 외적 환경 중 언어적인 환경(말속도, 발화길이 및 통사적 복잡성)의 변화에 따른 말더듬 아동과 일반아동의 비유창성 차이를 비교 분석하려고 한다. 연구대상은 4-6세 말더듬 아동 9명, 일반아동 9명이었다. 연구 과제로 문장 따라말하기 과제를 실시하여 말더듬 아동과 일반 아동의 비유창성 빈도를 구하였다. 두 그룹의 비유 창성 차이를 분석한 결과, 발화길이를 조절했을 때 평균 말속도에서 말더듬 아동은 발화길이와 상관없이 일반 아 동보다 비유창성이 더 많이 나타났다. 말속도를 조절 때 말더듬 아동은 빠른 말속도에서 일반아동보다 많은 비유 창성을 보였다. 그리고 말속도와 발화길이를 조절했을 시 빠른 말속도에서 말더듬 아동은 발화길이와 상관없이 일 반아동보다 높은 비유창성을 보였다. 통사적 복잡성을 조절했을 때는 복문에서 말더듬 아동이 일반아동보다 더 많 은 비유창성을 보였다. 말더듬 아동은 말속도, 발화길이 그리고 통사적 복잡성에 따라 비유창성에 영향을 받는 것 으로 나타났다. 이는 말더듬 아동은 말운동 조절 그리고 언어처리 능력이 일반아동보다 취약한 것으로 보인다. 따 라서 임상에서 말더듬 아동 치료 시 치료사와 부모가 말속도와 발화길이를 아동의 수준에 맞춰 진행하는 것이 중 요한 것으로 확인되었다.
\end{abstract}

핵심어: 말더듬, 요구용량 모델, 언어발달, 학령전기

\section{참고문헌}

김영태 (1996). 그림자음검사를 이용한 취학전 아동의 자음정확 도 연구. 언어청각장애연구, $1(1), 7-34$.

김영태 (2009). 수용 및 표현 어휘력 검사. 서울 : 서울 장애인 종합 복지관.

김정숙, 정승문 (2011). 문장의 길이와 구조에 따른 3-5 세 아동 의 문장 따라말하기 수행력. 언어치료연구, 20(2), 19-36.

고영근, 구본관 (2008). 우리 말 문법론. 서울: 집문당.

배소영, 임선숙, 이지희, 장혜성 (20004). 구문의미이해력 검사. 서울: 서울종합장애복지관.

심현섭, 신문자, 이은주(2011). 파라다이스-유창성 검사 II. 서울: 파라다이스복지재단.

심현섭, 김수진, 이희란, 김정미 (1999). 학령 전기 아동의 말속도 모방능력에 관한 연구. 음성과학, 5(1), 141-149.

이경재, 신지철, 김향희, 심현섭 (2003). 대화 상대자의 말속도 변 화에 따른 말더듬 아동의 변화: 학령전기 말더듬 아동의 말속 도와 말더듬 발생비율을 중심으로. 언어청각장애연구, $8(3)$, 134-148.

이소연, 심현섭, 신문자, 이수복 (2012). 조음복잡성에 따른 학령 전기 말더듬 아동과 일반아동의 이름대기 능력 비교. 언어청
각장애연구, 17(2), 219-233.

송윤경, 심현섭 (2008). 조음장애아동과 비장애아동의 말운동통 제 보상능력 비교. 음성과학, 15(3), 183-201. 